Program Studi Pendidikan Bahasa dan Sastra Indonesia

FKIP Universitas Kuningan

\title{
MENGUNGKAP IDEOLOGI TEKS BERITA COVID 19 BERDASARKAN PENDEKATAN ANALISIS WACANA KRITIS THEO VAN LEEUWEN
}

\author{
Resky Amalia ${ }^{1}$, Mahmudah $^{2}$, dan Mayong ${ }^{3}$ \\ Program Pascasarjana Magister Pendidikan Bahasa, Universitas Negeri Makassar, \\ Makassar, Sulawesi Selatan Indonesia \\ reskyamalia2203@gmail.com
}

\begin{abstract}
ABSTRAK: Penelitian ini bertujuan untuk (1) mengungkap ciri ideologi eksklusi pemberitaan Covid-19 mengenai tindak kejahatan dalam media daring SINDOnews.com dan Fajar.co.id model Theo van Leeuwen; (2) mengungkap ciri ideologi inklusi pemberitaan Covid-19 mengenai tindak kejahatan dalam media daring SINDOnews.com dan Fajar.co.id model Theo van Leeuwen; (3) mengindentifikasi perbedaan strategi eksklusi dan inklusi media daring SINDOnews.com dan Fajar.co.id pada pemberitaan Covid-19 mengenai tindak kejahatan. Penelitian ini merupakan penelitian kualitatif dengan menggunakan pendekatan paradigma kritis, sehingga metode pengumpulan data yang digunakan, yaitu teknik dokumentasi, teknik baca simak dan teknik pencatatan. Selain itu, teknik analisis data yang digunakan dalam penelitian ini, yaitu reduksi data, penyajian data, dan penyimpulan data. Sumber data dalam penelitian ini adalah media daring SINDOnews.com, cetakan Juli-September 2020. Ciri ideologi eksklusi dalam media daring SINDOnews.com dan Fajar.co.id, ditemukan adanya strategi wacana pasivasi dan nominalisasi. Ciri ideologi inklusi dalam media daring SINDOnews.com dan Fajar.co.id, ditemukan adanya strategi wacana objektivasi, nominasi, identifikasi, determinasi, indeterminasi, asimilasi dan individualisasi. Selain itu, terdapat tiga perbedaan pada strategi eksklusi dan inklusi dalam media daring SINDOnews.com dan Fajar.co.id.

Kata Kunci: Analisis Wacana Kritis; Fajar.co.id; SINDOnews.com; Teks Berita Covid-19
\end{abstract}

\section{REVEAL THE IDEOLOGY OF COVID-19 TEXT \\ BASED ON CRITICAL DISCOURSE APPROACH BY THEO VAN LEEUWEN}

\begin{abstract}
This research was aimed to (1) reveal the characteristic of the exclusion ideology of covid19 reporting about crime in online media of SINDOnews.com and Fajar.co.id Theo Van Leeuwen model; (2) ) reveal the characteristic of the inclusion ideology of covid-19 reporting about crime in online media of SINDOnews.com and Fajar.co.id Theo Van Leeuwen model; (3) identify the difference strategy of exclusion and inclusion online media of SINDOnews.com and Fajar.co.id at covid-19 reporting about crime. This research was quantitative research by using critical paradigm approach so that, data collection method used was documentation technique, reading-seeing technique, and recording technique. Besides that, the analysis data technique which was used in this research was data reduction, data presentation, and data inference. The source of data in this research was online media of SINDOnews.com, JulySeptember 2020 printing. Characteristic of exclusion ideology in online media of SINDOnews.com and Fajar.co.id, found there were passivation discourse strategy and nominalization. Characteristic of inclusion ideology in online media of SINDOnews.com and Fajar.co.id, found there were objectivation discourse strategy, nominations, identification, determination, indetermination, assimilation, and individualization. Besides that, there were three differences in exclusion and inclusion strategy in online media of SINDOnews.com and Fajar.co.id.
\end{abstract}

KEYWORDS: Covid-19 news text; critical discourse analysis; SINDOnews.com; Fajar.co.id

\begin{tabular}{cccc}
\hline Diterima: & Direvisi: & Distujui: & Dipublikasi: \\
2021-07-07 & 2021-07-08 & 2021-09-01 & 2021-10-29 \\
Pustaka & Amaliah, R., Mahmudah, M., \& Mayong, M. (2021). MENGUNGKAP IDEOLOGI TEKS \\
BERITA COVID 19 BERDASARKAN PENDEKATAN ANALISIS WACANA KRITIS & THEO VAN LEEUWEN. Fon: Jurnal Pendidikan Bahasa dan Sastra Indonesia, 17(2), 203- \\
215. doi:https://doi.org/10.25134/fon.v17i2.4439 & \\
\hline
\end{tabular}




\section{PENDAHULUAN}

Bahasa digunakan untuk saling mengadakan interaksi dalam kehidupan sehari-hari dan bahasa juga digunakan dalam bentuk wacana. Wacana merupakan proposisi yang saling berhubungan dengan proposisi lainnya dalam rentetan kalimat yang berkaitan, sehingga membentuk makna yang serasi di antara kalimat, serta membentuk satu kesatuan yang utuh (Badudu, 2000). Keutuhan atau kelengkapan makna menjadi hal yang terpenting di dalam wacana.

Seiring perkembangan zaman, wacana digunakan untuk memahami realitas. Bahasa dapat dijadikan sebagai praktik wacana yang dapat merepresentasikan atau memproyeksikan sebuah realitas (Sawirman, 2017). Realitas tersebut dapat terwujud melalui bentuk pemberitaan.

Beberapa bulan terakhir hingga saat ini, salah satu pemberitaan yang menggemparkan seluruh dunia dan menarik perhatian masyarakat adalah pemberitaan mengenai Covid 19. Pemberitaan Covid 19 tidak hanya menampilkan peristiwa mengenai jumlah pasien yang terkonfirmasi postif Covid 19 hingga yang meninggal dunia akibat pandemi tersebut, tetapi manampilkan peristiwa mengenai tindak kejahatan yang terjadi akibat Covid 19. Pemberitaan Covid 19 mengenai tindak kejahatan tidak hanya menampilkan sekadar peristiwa, tetapi juga melibatkan pihak-pihak atau aktor-aktor yang terdapat di dalam pemberitaan yang menyampaikan opini, fakta-fakta, tokoh utama yang menjadi pelaku di dalam pemberitaan, serta korban yang dirugikan di dalam peristiwa tersebut, sehingga terdapat makna atau ideologi tertentu dalam melibatkan aktor-aktor sosial.

Pada hakikatnya, aktor-aktor sosial yang terlibat di dalam pemberitaan dapat ditampilkan secara apa adanya, namun pada kenyataannya terdapat makna atau ideologi tersembunyi dalam melibatkan aktor-aktor sosial tersebut, sehingga pembaca tidak menyadari dan hanya fokus terhadap informasi dan peristiwa yang disajikan di dalam pemberitaan. Hal tersebut perlu diungkap secara mendalam melalui analisis wacana kritis.

Salah satu model analisis wacana kritis yang mampu mengungkap ideologi aktor-aktor sosial yang terlibat di dalam pemberitaan dibandingkan dengan model analisis wacana kritis lainnya, yaitu model Theo van Leeuwen, sehingga model tersebut memiliki kelebihan dalam mengungkap aktor-aktor sosial yang dihilangkan dan ditampilkan di dalam pemberitaan. Konsep dasar dari model Theo van Leeuwen, yaitu aktor-aktor sosial yang dikeluarkan dan ditampilkan dalam pemberitaan dengan menggunakan strategi wacana tertentu (Fauzan, 2014), sehingga aktor atau kelompok yang lebih dominan memegang kendali dan aktor atau kelompok lain yang tidak memegang kendali atau posisinya yang rendah cenderung dimarginalkan secara buruk, serta menjadi objek pemaknaan (Arsa, dkk, 2019).

Sumber data yang akan digunakan dalam penelitian ini adalah media daring SINDOnews.com dan Fajar.co.id. Pemilihan media daring SINDOnews.com, karena jumlah pengunjung pada laman tersebut menempati posisi ke 14 bedasarkan situs Alaexa.com pada tahun 2020 yang terermin dengan slogan sebagai informasi yang terpercaya, sehingga merupakan salah satu media terbesar dan populer di Indonesia. Adapun pemilihan media daring Fajar.co.id, karena media tersebut merupakan salah satu media terbesar dan populer di Indonesia timur, khususnya di kota makassar. Kedua media daring tersebut dianalisis dengan menggunakan pendekatan analisis wacana kritis Theo van Leeuwen. 
Program Studi Pendidikan Bahasa dan Sastra Indonesia FKIP Universitas Kuningan

Penelitian yang menggunakan model analisis wacana kritis Theo van Leeuwen telah banyak dilakukan, antara lain Analisis Wacana Kritis Kasus Penyerangan Terhadap Jemaah Ahmadiyah di Cikeusik oleh (Sari, 2018). Artikel ini membahas mengenai konstelasi kekuatan dalam berita kasus penyerangan Ahmadiyah di Cikeusik dan bagaimana representasi kelompok jemaah Ahmadiyah dalam berita tersebut. Berbeda dengan penelitian selanjutnya berjudul Analisis Wacana Kritis pada Berita Online Tempo.co Tentang Pilpres 2019 oleh (Pramita dkk., 2019). Artikel ini membahas mengenai penggunaan teori inklusi pada berita politik dan melihat keperpihakkan wartawan pada pilpers 2019 dalam berita media massa online Tempo.co. Penelitian selanjutnya juga berbeda berjudul Strategi Pemberitaan di Media Online Nasional Tentang Perkara Tercecernya KTP Elektronik ( Analisis Teori van Leeuwen) oleh (Rilma dkk., 2019). Artikel ini membahas mengenai perbedaan sudut pandang antara media online nasional Indonesia yaitu Vivanew.com,

Detiknews.com,

Kompas.com, Metrotvnes.com dan Sindonews.com dan mendeskripsikan kecenderungan sikap media online tersebut dalam mengonstruksikan kasus tercecernya KTP elektronik. Penelitian yang juga berbeda berjudul Critical Discourse Analysis of Theo van Leeuwen's Inclussion Theory on Anti-Crime Editorials in Daily Newspapers Pos Kota February 2020 Edition oleh (Hartono dkk., 2020). Artikel ini membahas mengenai sikap dan pandangan penulis terhadap kasus kriminalitas yang sering terjadi di Indonesia belakangan ini yang diwujudkan dalam wacana tajuk antikriminalitas. Penelitian yang turut menggunakan model Theo van Leeuwen juga berbeda berjudul Pemosisian Pelaku dan Korban dalam Berita Kriminal Tentang Pembunuhan di Berita Online Tribun News.com oleh (Hura dkk., 2020). Artikel ini membahas mengenai penggunaan teori inklusi Theo Van Leeuwen dalam berita kriminal pembunuhan di berita online tribun news.com.

Berdasarkan latar belakang tersebut, rumusal masalah dalam penelitian ini, yaitu (1) bagaimanakah ciri ideologi eksklusi pemberitaan Covid-19 mengenai tindak kejahatan dalam media daring SINDOnews.com dan Fajar.co.id model Theo van Leeuwen?; (2) bagaimanakah ciri ideologi inklusi pemberitaan Covid-19 mengenai tindak kejahatan dalam media daring SINDOnews.com dan Fajar.co.id model Theo van Leeuwen?; bagaimanakah perbedaan strategi eksklusi dan inklusi media daring SINDOnews.com dan Fajar.co.id pada pemberitaan Covid19 mengenai tindak kejahatan Model Theo van Leeuwen?. Adapun tujuan penelitian ini, yaitu (1) mengungkap ciri ideologi eksklusi pemberitaan Covid-19 mengenai tindak kejahatan dalam media daring SINDOnews.com dan Fajar.co.id model Theo van Leeuwen; (2) mengungkap ciri ideologi inklusi pemberitaan Covid-19 mengenai tindak kejahatan dalam media daring SINDOnews.com dan Fajar.co.id model Theo van Leeuwen; (3) mengidentifikasi perbedaan strategi eksklusi dan inklusi media daring SINDOnews.com dan Fajar.co.id pada pemberitaan Covid-19 mengenai tindak kejahatan Model Theo van Leeuwen. Penelitian ini diharapkan bermanfaat bagi masyarakat untuk memberikan informasi yang mendalam mengenai pengungkapan ciri ideologi aktor-aktor sosial yang dihilangkan dan ditampilkan di dalam pemberitaan.

\section{LANDASAN TEORI}

Wacana sebagai sebuah peristiwa diskursif tertentu dengan situasi, institusi dan struktur sosial yang mewadahi adanya hubungan dialektik yang menyiratkan bentuk "praktik sosial" yang digunakan dalam tuturan dan tulisan (Fairlough, 
Program Studi Pendidikan Bahasa dan Sastra Indonesia FKIP Universitas Kuningan

1995), serta wacana memuat konotasi yang dapat menyembunyikan ideologi tertentu (Marheni dkk., 2020), sehingga konsep analisis bahasa kritis (Critical Language Awareness) mengawali munculnya analisis wacana kritis. Analisis wacana kritis merupakan kajian wacana yang menganalisis praktik kekuasaan sebagai alat untuk mengontrol sesuatu yang berhubungan dengan masyarakat, sehingga wacana dapat menjadi salah satu bentuk praktik kekuasaan di tengah masyarakat yang bertindak dalam membangun ideologi tertentu (Kholid, 2018), serta menyelidiki mengenai bahasa yang mencerminkan adanya praktik sosial (Othman, 2019).

Tujuan utama analisis wacana kritis, yaitu menyingkap bahasa yang digunakan untuk mengungkap ketidakadilan kekuasaan yang terdapat di masyarakat pada proses praktik sosial tertentu, sehingga aktivitas berbahasa dalam konteks sosial tidak hanya menjadi wujud ekspresi atau refleksi di antara para partisipan wacana linguistik (Masitoh, 2020). Analisis wacana kritis tidak hanya sekadar kajian bahasa, meskipun analisis wacana kritis menggunakan bahasa dalam teks dengan tujuan untuk dianalisis, tetapi hasil dari analisis tersebut bukan hanya memperoleh gambaran dari aspek kebahasaan, tetapi menyangkut pautkannya dengan konteks.

Terdapat beberapa model analisis wacana kritis yang dapat digunakan dalam melakukan kajian empiris mengenai hubungan antara wacana dan perkembangan kultural dalam domaindomain yang berbeda, serta perkembangan sosial, salah satunya adalah analisis wacana kritis Theo van Leeuwen. Analisis Theo van Leeuwen secara umum menampilkan aktor-aktor sosial yang dihilangkan dan ditampilkan di dalam pemberitaan. Theo van Leeuwen menggunakan model analisis wacana kritis untuk mengkaji peristiwa aktor-aktor sosial yang dihilangkan dan ditampilkan di dalam teks, serta adanya kelompok yang terus-menerus dimarginalkan (Darma, 2014: 151).

Terdapat dua bagian dalam pendekatan analisis wacana kritis Theo van Leeuwen, yaitu (1) proses pengeluaran (eksklusi) adalah aktor-aktor sosial yang dihilangkan dalam teks pemberitaan dengan menggunakan strategi wacana yang terdiri dari pasivasi, nominalisasi dan penggantian anak kalimat dan (2) proses pemasukan (inklusi) adalah aktor-aktor sosial yang ditampilkan dalam teks pemberitaan dengan menggunakan strategi wacana diferensiasi-indiferensiasi, objektivasi-abstraksi, nominasikategorisasi, nominasi-identifikasi, determinasi-indeterminasi, asimilasiindividualisasi, dan asosiasi-disosiasi. (Darma 2014: 151). Berdasarkan sudut pandang Theo van Leeuwen (2008: 28-47) strategi wacana pada proses pengeluaran (eksklusi) dan proses pemasukan (inklusi) aktor-aktor sosial, yaitu sebagai berikut ini.

\section{Proses Pengeluaran (Eksklusi)}

a. Pasivasi merupakan strategi pengubahan kalimat aktif menjadi bentuk penggunaan kalimat pasif, sehingga aktor-aktor sosial tidak dihadirkan dalam teks.

b. Nominalisasi merupakan strategi pengubahan kata kerja (verba) menjadi bentuk penggunaan kata benda (nomina) yang menghilangkan aktoraktor sosial di dalam teks dengan memberikan imbuhan pe-an, sehingga bermakna peristiwa.

c. Penggantian anak kalimat merupakan penggunaan anak kalimat yang sekaligus berfungsi sebagai pengganti subjek untuk menghilangkan aktoraktor sosial di dalam teks.

Pada SINDOnews.com ditemukan strategi wacana pasivasi dan nominalisasi. Adapun Fajar.co.id ditemukan strategi wacana pasivasi.

Proses Pemasukan (Inklusi) 
Program Studi Pendidikan Bahasa dan Sastra Indonesia FKIP Universitas Kuningan

\section{a. Diferensiasi-Indiferensiasi}

Diferensiasi merupakan adanya peristiwa aktor-aktor sosial yang ditampilkan secara kontras dengan aktor yang lain di dalam teks, sehingga hadirnya aktor tersebut secara tidak langsung menunjukkan bahwa aktor tersebut tidak baik dibandingkan dengan aktor lainnya. Hal tersebut merupakan strategi untuk memarginalkan aktor atau kelompok sosial. Adapun indiferensiasi merupakan adanya peristiwa aktor-aktor sosial yang ditampilkan secara mandiri tanpa dikontraskan dengan aktor yang lain di dalam teks.

\section{b. Objektivasi-Abstraksi}

Objektivasi merupakan adanya peristiwa aktor-aktor sosial yang ditampilkan dengan memberi petunjuk atau informasi yang konkret. Adapun abstraksi merupakan adanya peristiwa aktor-aktor sosial yang ditampilkan tidak memberi petunjuk atau informasi yang kongkret, seperti menggunakan kata banyak, banyak sekali, berulang-ulang, dan lain sebagainya, sehingga dampak terhadap makna yang diterima oleh pembaca akan berbeda.

\section{c. Nominasi-Kategorisasi}

Nominasi merupakan adanya peristiwa aktor-aktor sosial yang ditampilkan secara apa adanya. Adapun kategorisasi merupakan adanya peristiwa aktor-aktor sosial yang ditampilkan dengan menyebut kategori sosialnya, seperti agama, ras, status, bentuk fisik, dan ciri penting dari aktor tersebut, sehingga kategori ini dimaksudkan untuk memarginalkan aktor atau kelompok sosial tertentu di dalam teks.

\section{d. Nominasi-Identifikasi}

Nominasi merupakan adanya peristiwa aktor-aktor sosial yang ditampilkan secara apa adanya. Adapun identifikasi adanya peristiwa aktor-aktor sosial yang ditampilkan dengan mendefinisikan secara kelompok, baik dari kategori sosialnya, fisik, serta peristiwa atau tindakan tertentu dengan cara memberi anak kalimat sebagai penjelas, sehingga mensugestikan makna tertentu.

\section{e. Determinasi-Indeterminasi}

Determinasi merupakan adanya peristiwa aktor-aktor sosial yang ditampilkan secara anonim (tidak jelas) dan akan menimbulkan efek generalisasi apabila anonim yang digunakan dalam bentuk plural, seperti banyak orang atau sebagian orang. Adapun indeterminasi merupakan adanya peristiwa aktor-aktor sosial yang ditampilkan secara jelas.

\section{f. Asimilasi-Individualisasi}

Asimilasi merupakan adanya peristiwa aktor-aktor sosial yang ditampilkan dengan menunjukkan komunitas tempat aktor tersebut berada, sehingga seakan-akan terjadi efek generalisasi. Adapun individualisasi merupakan adanya peristiwa aktor-aktor sosial yang ditampilkan dengan jelas kategorinya secara spesifik.

\section{g. Asosiasi-Disosiasi}

Asosiasi merupakan adanya peristiwa aktor-aktor sosial yang dihubungkan dengan kelompok lain yang lebih besar. Kelompok yang lebih besar ini menunjuk tempat-tempat aktor tersebut berada, sehingga pembaca akan membayangkan dan menghubungkan secara imajiner dengan komunitas yang lebih luas pernyataannya. Adapun disosiasi merupakan adanya peristiwa aktor-aktor sosial yang ditampilkan sendiri tanpa dihubungkan dengan kelompok lain yang lebih besar.

Pada SINDOnews.com ditemukan strategi wacana terhadap aktor-aktor sosial yang direpresentasikan secara apa adanya yang terdiri atas strategi wacana objektivasi, indeterminasi dan individualisasi. Adapun strategi wacana terhadap aktor-aktor sosial yang direpresentasikan melalui maksud atau makna tertentu terdiri atas strategi wacana determinasi dan asimilasi. Selain itu, pada Fajar.co.id ditemukan strategi wacana 
Program Studi Pendidikan Bahasa dan Sastra Indonesia FKIP Universitas Kuningan

terhadap aktor-aktor sosial yang direpresentasikan secara apa adanya yang terdiri atas strategi wacana objektivasi, nominasi, indeterminasi dan individualisasi. Adapun strategi wacana terhadap aktor-aktor sosial yang direpresentasikan melalui maksud atau makna tertentu, yaitu strategi wacana identifikasi.

\section{METODE}

Penelitian kualitatif berkaitan dengan dinamika hubungan antara fenomena yang diamati dan menggunakan logika ilmiah, sehingga menekankan analisis proses berpikir secara deduktif dan induktif (Hardani dkk., 2020: 248). Adapun penelitian ini menggunakan jenis penelitian kualitatif dengan menggunakan pendekatan paradigma kritis yang dikategorikan dalam penelitian analisis wacana kritis. Data dalam penelitian ini adalah kata, frasa, klausa dan kalimat yang berkaitan dengan model analisis wacana kritis Theo van Leeuwen.

Sumber data dalam penelitian ini, yaitu media daring SINDOnews.com dan Fajar.co.id pada pemberitaan Covid 19 mengenai tindak kejahatan, serta beberapa buku dan jurnal yang mendukung penelitian ini. Selain itu, teknik pengumpulan data dalam penelitian ini, yaitu (1) dokumentasi dilakukan untuk mengumpulkan teks pemberitaan Covid-19 mengenai tindak kejahatan dalam media daring SINDOnews.com dan Fajar.co.id dalam rentang waktu bulan Juli-September 2020; (2) baca simak dilakukan untuk mencermati dan memilah data yang sesuai dengan model analisis wacana kritis Theo van Leeuwen pada pemberitaan Covid 19 mengenai tindak kejahatan dalam media daring SINDOnews.com dan Fajar.co.id; (3) pencatatan dilakukan dengan cara mengutip teks pemberitaan Covid 19 mengenai tindak kejahatan dalam media daring SINDOnews.com dan Fajar.co.id dengan menggunakan panduan analisis wacana kritis model Theo van Leeuwen.

Tahap selanjutnya, yaitu analisis data dengan menggunakan pendekatan analisis wacana kritis Theo van Leeuwen yang terdiri dari eksklusi dan inklusi. Kegiatan analisis data dilakukan dengan prosedur: (1) reduksi data dengan membaca seluruh isi berita Covid 19 mengenai tindak kejahatan dalam media daring SINDOnews.com dan Fajar.co.id dan memilah data yang sesuai dengan model analisis wacana kritis Theo van Leeuwen; (2) penyajian data dengan mengungkap ciri ideologi eksklusi dengan menggunakan strategi wacana tertentu dan mengungkap ciri ideologi inklusi dengan menggunakan strategi wacana tertentu, serta mengidentifikasi perbedaan strategi eksklusi dan inklusi dalam media daring SINDOnews.com dan Fajar.co.id; (6) penyimpulan data dengan menarik kesimpulan berdasarkan reduksi dan penyajian data.

\section{HASIL DAN PEMBAHASAN \\ Ciri Ideologi Eksklusi}

\section{Media daring SINDOnews.com (Pelaku Dugaan Penyelewengan Bansos COVID-19 dari Ketua RT hingga Kadinsos)}

a) Pasivasi

(1)Belasan kasus itu dilaporkan ke polisi karena diduga ada dugaan penyelewengan dan pungutan liar (pungli).

Kutipan teks berita tersebut, termasuk strategi pengubahan kalimat aktif menjadi bentuk penggunaan kalimat pasif, sehingga aktor-aktor sosial tidak dihadirkan dalam teks yang ditandai dengan kata dilaporkan dan diduga, maka ciri ideologi pada data tersebut, yaitu hilangnya aktor yang melaporkan adanya belasan kasus penyelewengan dan pungutan liar (pungli) ke polisi dan hilangnya aktor yang menduga adanya penyelewengan dan pungutan liar (pungli) 
Program Studi Pendidikan Bahasa dan Sastra Indonesia FKIP Universitas Kuningan

dapat melegitimasikan pemahaman pembaca terhadap belasan kasus penyelewengan dan pungutan liar yang menjadi objek pemaknaan. Hal tersebut menyebabkan pembaca hanya fokus terhadap belasan kasus penyelewengan dan pungutan liar tanpa mengetahui aktor yang melaporkan dan menduga adanya kasus tersebut, sehingga belasan kasus penyelewengan dan pungutan liar (pungli) dialamatkan sebagai tindakan yang sedang marak terjadi ditengah pandemi Covid-19 yang dimanfaatkan untuk memperoleh keuntungan dengan mengambil hak warga yang terdampak Covid-19 dan adanya sejumlah permintaan dengan persyaratan melakukan pembayaran untuk memperoleh bantuan baik berupa sembako maupun dana bansos Covid-19.

b) Nominalisasi

(2)Meski ada dugaan mens rea atau niat jahat memperkaya diri sendiri dan orang lain, ungkap Yaved, seluruh 13 kasus penyelewengan bansos itu masih dalam proses penyelidikan.

Kutipan teks berita tersebut, termasuk strategi pengubahan kata kerja (verba) menjadi bentuk penggunaan kata benda (nomina) yang menghilangkan aktor-aktor sosial di dalam teks dengan memberikan imbuhan pe-an, sehingga bermakna peristiwa yang ditandai dengan kata penyelewengan dan penyelidikan, maka ciri ideologi pada data tersebut, yaitu hilangnya aktor yang menyelewengkan dana bansos Covid-19 dan hilangnya aktor yang menyelidiki 13 kasus penyelewengan dana bansos Covid-19 dapat melegitimasikan pemahaman pembaca terhadap tindakan menyelewengkan dan menyelidiki yang telah diubah fungsinya menjadi peristiwa penyelewengan dan penyelidikan. Hal tersebut dapat menyentuh emosi pembaca terhadap peristiwa penyelewengan dana bansos Covid-19 dengan dugaan memperkaya diri sendiri, serta orang lain dan peristiwa penyelidikan terhadap 13 kasus penyelewengan tersebut, sehingga dengan adanya tindak kejahatan penyelewengan dana bansos Covid-19 karena adanya bentuk penyalahgunaan kekuasaan secara diam-diam dengan mengelabui pemerintah yang diberikan kewenangan dengan menitipkan dana tersebut untuk dibagikan ke masyarakat yang terdampak ekonominya akibat Covid-19. Selain itu, adanya 13 kasus penyelewengan telah melanggar pasal dan undang-undang yang telah ditetapkan dan dianggap merugikan banyak pihak, sehingga penyelidikan harus dilakukan untuk mengusut tuntas kasus tersebut karena telah mengambil hak warga yang terdampak Covid-19.

2. Media daring Fajar.co.id (Irenanda dan Linda Kurniawati Bawa Uang Bansos Covid-19 Rp135 Juta, 4 Kawanan Rampok Beraksi)

a) Pasivasi

(3)Uang tersebut, awalnya untuk disalurkan kelima desa di Kecamatan Pondoksalam di antaranya yakni Desa Situ, Sukajadi, Parakansalam, Salem dan Desa Galudra.

Kutipan teks berita tersebut, termasuk strategi pengubahan kalimat aktif menjadi bentuk penggunaan kalimat pasif, sehingga aktor-aktor sosial tidak dihadirkan dalam teks yang ditandai dengan kata disalurkan, maka ciri ideologi pada data tersebut, yaitu hilangnya aktor yang menyalurkan uang bansos Covid-19 pada kelima desa di Kecamatan Pondoksalam dapat melegitimasikan pemahaman pembaca terhadap uang bansos yang menjadi objek pemaknaan. Hal tersebut menyebabkan pembaca hanya fokus terhadap uang bansos tanpa mengetahui aktor yang menyalurkan uang bansos Covid-19 tersebut, sehingga uang bansos tersebut dialamatkan sebagai bantuan berupa uang yang awalnya akan diberikan pada lima desa, yaitu Desa Situ, Sukajadi, Parakansalam, Salem dan Desa Galudra di Kecamatan Pondoksalam yang 
Program Studi Pendidikan Bahasa dan Sastra Indonesia FKIP Universitas Kuningan

ekonominya terdampak akibat Covid-19, namun uang bansos tersebut malah dirampok oleh pelaku yang mengahalkan segala cara dalam melakukan aksi kejahatannya untuk memiliki uang tersebut.

\section{Ciri Ideologi Inklusi}

1. Media daring SINDOnews.com (Pelaku Dugaan Penyelewengan Bansos COVID-19 dari Ketua RT hingga Kadinsos)

a) Objektivasi

(1)Direktorat Reserse Kriminal Khusus Polda Jawa Barat Polda Jabar mengungkap para pelaku 13 kasus dugaan penyelewengan dana bantuan sosial (bansos) bagi warga terdampak pandemi COVID-19 yang tengah diselidiki.

Kutipan teks berita tersebut, termasuk peristiwa aktor-aktor sosial yang ditampilkan dengan memberi petunjuk atau informasi yang konkret yang ditandai dengan kata 13 kasus, sehingga ciri ideologi pada data tersebut, yaitu Direktorat Reserse Kriminal Khusus Polda Jabar direpresentasikan dengan memberi petunjuk atau informasi yang konkret bahwa sebanyak 13 kasus dugaan penyelewengan dana bantuan sosial (bansos) Covid-19 yang telah diungkap yang dilakukan oleh para pelaku yang menyalahgunakan kekuasannya untuk memperoleh keuntungan dari bantuan tersebut. Dengan demikian, aktor tersebut ditampilkan dengan memberi petunjuk atau informasi yang konkret tanpa melegitimasikan pemahaman pembaca.

b) Determinasi

(2)Direktorat Reserse Kriminal Khusus Polda Jawa Barat Polda Jabar mengungkap para pelaku 13 kasus dugaan penyelewengan dana bantuan sosial (bansos) bagi warga terdampak pandemi COVID-19 yang tengah diselidiki.

Kutipan teks berita tersebut, termasuk peristiwa aktor-aktor sosial yang ditampilkan secara anonim (tidak jelas) dan akan menimbulkan efek generalisasi apabila anonim yang digunakan dalam bentuk plural yang ditandai dengan kata para pelaku, sehingga ciri ideologi pada data tersebut, yaitu para pelaku direpresentasikan secara anonim dalam bentuk plural. Hal tersebut dapat menimbulkan efek generalisasi yang dapat melegitimasikan pemahaman pembaca bahwa dengan adanya 13 kasus dugaan penyelewengan dana bantuan sosial (bansos) Covid-19 yang telah berhasil diungkap dapat membuktikan bahwa terdapat beberapa pelaku yang telah menyalahgunakan kekuasannya dalam mengambil hak warga yang terdampak Covid-19 untuk memenuhi kebutuhan dan kepentingan pribadi para pelaku.

c) Indeterminasi

(3)Kombes Pol Yaved mengemukakan, modus para pelaku dalam sejumlah kasus dugaan penyelewengan bansos itu beragam.

Kutipan teks berita tersebut, termasuk peristiwa aktor-aktor sosial yang ditampilkan secara jelas yang ditandai dengan Yaved, sehingga ciri ideologi pada data tersebut, yaitu aktor tersebut direpresentasikan dengan menyebut nama Kombes Pol secara jelas yang memberikan keterangan mengenai adanya modus para pelaku yang melakukan tindak kejahatan penyelewengan dana bansos Covid-19 dengan berbagai macam niat terselubung untuk memiliki dana tersebut. Dengan demikian, aktor tersebut ditampilkan secara jelas tanpa melegitimasikan pemahaman pembaca.

d) Asimilasi

(4)Penyelewengan bansos COVID-19 tersebut diduga dilakukan oleh aparat kewilayahan, seperti camat, kepala desa, perangkat desa, ketua $R T$ dan $R W$.

Kutipan teks berita tersebut, termasuk peristiwa aktor-aktor sosial yang ditampilkan dengan menunjukkan 
Program Studi Pendidikan Bahasa dan Sastra Indonesia FKIP Universitas Kuningan

komunitas tempat aktor tersebut berada yang ditandai dengan kata camat, kepala desa, perangkat desa, ketua $R T$ dan $R W$, sehingga ciri ideologi pada data tersebut, yaitu dikesankan begitu banyak camat, kepala desa, perangkat desa, ketua RT dan RW yang berprofesi sebagai aparat kewilayahan yang diduga melakukan penyelewengan dana bansos Covid-19. Hal tersebut dapat menimbulkan efek generalisasi yang dapat melegitimasikan pemahaman pembaca bahwa semua camat, kepala desa, perangkat desa, ketua RT dan RW yang berprofesi sebagai aparat kewilayahan bersaing secara buruk untuk memenuhi ketamakannya dengan melakukan tindak kejahatan penyelewengan dana bansos Covid-19.

e) Individualisasi

(5)Kombes Pol Yaved mengemukakan, modus para pelaku dalam sejumlah kasus dugaan penyelewengan bansos itu beragam.

Kutipan teks berita tersebut, termasuk peristiwa aktor-aktor sosial yang ditampilkan dengan jelas kategorinya secara spesifik yang ditandai dengan kata Kombes Pol Yaved, sehingga ciri ideologi pada data tersebut, yaitu aktor tersebut direpresentasikan dengan jelas kategorinya secara spesifik bahwa Komisaris Besar Polisi dengan tingkat perwira menengah yang bernama Yaved yang memberikan keterangan adanya modus para pelaku yang melakukan tindak kejahatan penyelewengan dana bansos Covid-19 dengan berbagai macam niat terselubung untuk memiliki dana tersebut dengan mengambil hak warga yang terdampak Covid-19. Dengan demikian, aktor tersebut ditampilkan dengan jelas kategorinya secara spesifik tanpa melegitimasikan pemahaman pembaca.

\section{Media daring Fajar.co.id (Irenanda dan Linda Kurniawati Bawa Uang Bansos Covid-19 Rp135 Juta, 4 Kawanan Rampok Beraksi)}

a) Objektivasi
(6)Bantuan untuk Keluarga Penerima Manfaat (KPM) pada lima desa di Kecamatan Pondoksalam, Purwakarta itu jumlahnya tak kurang dari Rp135 juta.

Kutipan teks berita tersebut, termasuk peristiwa aktor-aktor sosial yang ditampilkan dengan memberi petunjuk atau informasi yang konkret yang ditandai dengan kata lima desa dan Rp135 juta, sehingga ciri ideologi pada data tersebut, yaitu Keluarga Penerima Manfaat (KPM) direpresentasikan dengan memberi petunjuk atau informasi yang konkret yang berhak untuk menerima dana bansos Covid-19 pada lima desa di Kecamatan Pondoksalam, Purwakarta yang jumlahnya tak kurang dari Rp135 juta. Dengan demikian, aktor tersebut ditampilkan dengan memberi petunjuk atau informasi yang konkret tanpa melegitimasikan pemahaman pembaca.

b) Nominasi

(7)Perampokan tersebut dialami oleh Staf Desa Salem bernama Irenanda (20) dan Bendahara Desa Situ, Kecamatan Pondoksalam bernama Linda Kurniawati (29) di Jalan Kampung Sawah Tengah, Desa Pasawahan Kidul, Kecamatan Pasawahan, Purwakarta, pada Senin (31/8) sekitar pukul 09.00 WIB.

Kutipan teks berita tersebut, termasuk peristiwa aktor-aktor sosial yang ditampilkan secara apa adanya yang ditandai dengan Staf Desa Salem bernama Irenanda dan Bendahara Desa Situ, Kecamatan Pondoksalam bernama Linda Kurniawati, sehingga ciri ideologi pada data tersebut, yaitu Irenda sebagai Staf Desa Salem dan Linda Kurniawati sebagai Bendahara Desa Situ, Kecamatan Pondoksalam direpresentasikan secara apa adanya dengan peristiwa yang dialami oleh kedua korban tersebut yang mengalami tindak kejahatan perampokan dana bansos Covid-19 di Jalan Kampung Sawah Tengah, Desa Pasawahan Kidul, 
Program Studi Pendidikan Bahasa dan Sastra Indonesia FKIP Universitas Kuningan

Kecamatan Pasawahan, Purwakarta, pada Senin (31/8) sekitar pukul 09.00 WIB. Dengan demikian, aktor tersebut ditampilkan secara apa adanya tanpa melegitimasikan pemahaman pembaca.

c) Identifikasi

(8)Selain menggondol duit, kawanan rampok juga melukai kedua korban hingga terkapar di tengah jalan.

Kutipan teks berita tersebut, termasuk peristiwa aktor-aktor sosial yang ditampilkan dengan mendefinisikan secara kelompok, baik dari kategori sosialnya, fisik, serta peristiwa atau tindakan tertentu dengan cara memberi anak kalimat sebagai penjelas yang ditandai dengan penggunaan anak kalimat juga melukai kedua korban hingga terkapar di tengah jalan, sehingga ciri ideologi pada data tersebut, yaitu kawanan rampok direpresentasikan secara buruk dengan tindakan yang telah dilakukan dalam menjalakan aksi kejahatannya. Hal tersebut dapat mensugestikan makna tertentu yang dapat melegitimasikan pemahaman pembaca bahwa tindak kejahatan yang dilakukan oleh kawanan perampok tersebut tidak hanya merampas uang dana bansos Covid19, tetapi juga melakukan kekerasan fisik terhadap kedua kedua korban untuk memudahkan para pelaku dalam melancarkan aksi kejahatannya.

d) Indeterminasi

(9)Perampokan tersebut dialami oleh Staf Desa Salem bernama Irenanda (20) dan Bendahara Desa Situ, Kecamatan Pondoksalam bernama Linda Kurniawati (29) di Jalan Kampung Sawah Tengah, Desa Pasawahan Kidul, Kecamatan Pasawahan, Purwakarta, pada Senin (31/8) sekitar pukul 09.00 WIB.

Kutipan teks berita tersebut, termasuk peristiwa aktor-aktor sosial yang ditampilkan secara jelas yang ditandai dengan Irenanda dan Linda Kurniawati, sehingga ciri ideologi pada data tersebut, yaitu aktor tersebut direpresentasikan dengan menyebut nama Staf Desa Salem dan menyebut nama Bendahara Desa Situ, Kecamatan Pondoksalam secara jelas yang menjadi korban dalam tindak kejahatan perampokan dana bansos Covid-19 yang terjadi di Jalan Kampung Sawah Tengah, Desa Pasawahan Kidul, Kecamatan Pasawahan, Purwakarta, pada 31 agustus 2020 sekitar pukul 09.00 WIB. Dengan demikian, aktor tersebut ditampilkan secara jelas tanpa melegitimasikan pemahaman pembaca.

e) Individualisasi

(10)Perampokan tersebut dialami oleh Staf Desa Salem bernama Irenanda (20) dan Bendahara Desa Situ, Kecamatan Pondoksalam bernama Linda Kurniawati (29) di Jalan Kampung Sawah Tengah, Desa Pasawahan Kidul, Kecamatan Pasawahan, Purwakarta, pada Senin (31/8) sekitar pukul 09.00 WIB.

Kutipan teks berita tersebut, termasuk peristiwa aktor-aktor sosial yang ditampilkan dengan jelas kategorinya secara spesifik yang ditandai dengan kata Staf Desa Salem bernama Irenanda dan Bendahara Desa Situ, Kecamatan Pondoksalam bernama Linda Kurniawati, sehingga ciri ideologi pada data tersebut, yaitu aktor tersebut direpresentasikan dengan jelas kategorinya secara spesifik bahwa Staf Desa Salem yang bernama Irenanda dan Bendahara Desa Situ, Kecamatan Pondoksalam yang bernama Linda Kurniawati menjadi korban dalam tindak kejahatan perampokan dana bansos Covid-19 yang terjadi di Jalan Kampung Sawah Tengah, Desa Pasawahan Kidul, Kecamatan Pasawahan, Purwakarta, pada 31 agustus 2020 sekitar pukul 09.00 WIB. Dengan demikian, aktor tersebut ditampilkan dengan jelas kategorinya secara spesifik tanpa melegitimasikan pemahaman pembaca. 
Program Studi Pendidikan Bahasa dan Sastra Indonesia

FKIP Universitas Kuningan

\section{Perbedaan strategi eksklusi dan inklusi}

Berdasarkan ciri ideologi eksklusi

dan inklusi pemberitaan Covid-19 mengenai tindak kejahatan dalam media daring SINDOnews.com dan Fajar.co.id, maka akan diidentifikasi perbedaan strategi eksklusi dan inklusi pada kedua media tersebut, yaitu sebagai berikut ini.

Tabel 1. Strategi Eksklusi Media Daring SINDOnews.com dan Fajar.co.id.

\begin{tabular}{|l|c|c|}
\hline $\begin{array}{l}\text { Strategi } \\
\text { Eksklusi }\end{array}$ & SINDOnews.com & Fajar.co.id. \\
\hline Pasivasi & 4 & 3 \\
\hline Nominalisasi & 4 & - \\
\hline $\begin{array}{l}\text { Penggantian } \\
\text { Anak } \\
\text { Kalimat }\end{array}$ & - & - \\
\hline \multicolumn{1}{|c|}{ Total } & $\mathbf{8}$ & $\mathbf{3}$ \\
\hline
\end{tabular}

Pada tabel tersebut terlihat bahwa strategi eksklusi media daring SINDOnews.com, yaitu terdapat strategi wacana pasivasi sebanyak 4 data dan strategi wacana nominalisasi sebanyak 4 data. Adapun strategi eksklusi media daring Fajar.co.id, yaitu hanya terdapat strategi wacana pasivasi sebanyak 3 data. Dengan demikian, perbedaan strategi eksklusi dalam media daring SINDOnews.com dan Fajar.co.id, yaitu media daring SINDOnews.com lebih mengarah pada penggunaan strategi wacana pasivasi dan nominalisasi dibandingkan dengan media daring Fajar.co.id.

Tabel 2. Strategi Inklusi Media Daring SINDOnews.com dan Fajar.co.id.

\begin{tabular}{|l|c|c|}
\hline \multicolumn{1}{|c}{$\begin{array}{c}\text { Strategi } \\
\text { Eksklusi }\end{array}$} & SINDOnew.com & Fajar.co.id. \\
\hline \multirow{2}{*}{$\begin{array}{l}\text { Diferensiasi } \\
\text { Indiferensiasi }\end{array}$} & - & - \\
\cline { 2 - 3 } $\begin{array}{l}\text { Objektivasi } \\
\text { Abstraksi }\end{array}$ & - & - \\
\cline { 2 - 3 } Nominasi & - & 9 \\
\cline { 2 - 3 } Kategorisasi & - & - \\
\hline Nominasi & - & - \\
Identifikasi & - & 3 \\
\hline \multirow{2}{*}{$\begin{array}{l}\text { Determinasi } \\
\text { Indeterminasi }\end{array}$} & - & 3 \\
\cline { 2 - 3 } & 4 & - \\
\hline
\end{tabular}

\begin{tabular}{|l|c|c|}
\hline \multirow{2}{*}{ Asimilasi } & 5 & - \\
\cline { 2 - 3 } Individualisasi & 3 & 3 \\
\hline Asosiasi & - & - \\
\hline Disosiasi & - & - \\
\hline Total & $\mathbf{2 3}$ & $\mathbf{2 1}$ \\
\hline
\end{tabular}

Pada tabel tersebut terlihat bahwa strategi inklusi media daring SINDOnews.com, yaitu aktor-aktor sosial yang direpresentasikan secara apa adanya dengan menggunakan strategi wacana objektivasi sebanyak 7 data, strategi wacana indeterminasi sebanyak 4 data dan strategi wacana individualisasi sebanyak 3 data. Adapun aktor-aktor sosial yang direpresentasikan melalui maksud atau makna tertentu dengan menggunakan strategi wacana determinasi sebanyak 4 data dan strategi wacana asimilasi sebanyak 5 data.

Selain itu, strategi inklusi media daring Fajar.co.id, yaitu aktor-aktor sosial yang direpresentasikan secara apa adanya dengan menggunakan strategi wacana objektivasi sebanyak 9 data, strategi wacana nominasi sebanyak 3 data, strategi wacana indeterminasi sebanyak 3 data dan strategi wacana individualisasi sebanyak 3 data. Adapun aktor-aktor sosial yang direpresentasikan melalui maksud atau makna tertentu dengan menggunakan strategi wacana determinasi sebanyak 4 data dan strategi wacana identifikasi sebanyak 3 data.

Dengan demikian, perbedaan strategi eksklusi dalam media daring SINDOnews.com dan Fajar.co.id, yaitu media daring Fajar.co.id lebih mengarah pada penggunaan strategi wacana objektivasi dibandingkan dengan media daring SINDOnews.com. Perbedaan selanjutnya, yaitu media daring Fajar.co.id lebih mengarah pada penggunaan strategi wacana terhadap aktor-aktor sosial yang direpresentasikan secara apa adanya, karena terdapat penggunaan strategi wacana objektivasi, nominasi, indeterminasi dan individualisasi dibandingkan dengan media daring 
Program Studi Pendidikan Bahasa dan Sastra Indonesia FKIP Universitas Kuningan

SINDOnews.com yang tidak ditemukan adanya strategi wacana nominasi. Perbedaan lainnya, yaitu media daring SINDOnews.com lebih mengarah pada strategi wacana terhadap aktor-aktor sosial yang direpresentasikan melalui maksud atau makna tertentu, karena terdapat penggunaan strategi wacana determinasi dan asimilasi, dibandingkan dengan media daring Fajar.co.id yang hanya terdapat penggunaan strategi wacana identifikasi.

\section{PENUTUP}

Berdasarkan rumusan masalah dan tujuan penelitian yang dipaparkan pada bagian pendahuluan sebelumnya, maka dapat disimpulkan hasil penelitian, yaitu:

1. ciri ideologi eksklusi pemberitaan Covid-19 mengenai tindak kejahatan dalam media daring SINDOnews.com dan Fajar.co.id berupa strategi wacana pasivasi dan nominalisasi terhadap aktor-aktor sosial yang dihilangkan dalam teks berita.

2. Ciri ideologi inklusi pemberitaan Covid-19 dalam media daring SINDOnews.com dan Fajar.co.id, yaitu terdapat penggunaan strategi wacana terhadap aktor-aktor sosial yang direpresentasikan secara apa adanya yang terdiri atas strategi wacana objektivasi, nominasi, indeterminasi dan individualisasi. Selain itu, ciri ideologi inklusi pemberitaan Covid-19 dalam media daring Fajar dan Sindo, yaitu terdapat penggunaan strategi wacana terhadap aktor-aktor sosial yang direpresentasikan melalui maksud atau makna tertentu yang terdiri atas strategi wacana determinasi, asimilasi dan individualisasi.

3. Perbedaan strategi eksklusi dalam media daring SINDOnews.com dan Fajar.co.id, yaitu media daring Fajar.co.id lebih mengarah pada penggunaan strategi wacana objektivasi dibandingkan dengan media daring SINDOnews.com. Perbedaan selanjutnya, yaitu media daring Fajar.co.id lebih mengarah pada penggunaan strategi wacana terhadap aktor-aktor sosial yang direpresentasikan secara apa adanya, dibandingkan dengan media daring SINDOnews.com. Perbedaan lainnya, yaitu media daring SINDOnews.com lebih mengarah pada strategi wacana terhadap aktor-aktor sosial yang direpresentasikan melalui maksud atau makna tertentu, dibandingkan dengan media daring Fajar.co.id.

Temuan hasil penelitian ini diharapkan kepada media pemberitaan seyogianya menampilkan aktor-aktor sosial secara objektif agar pembaca tidak hanya fokus terhadap aktor dan peristiwa tertentu, sehingga ketika dibaca dan diterima oleh pembaca tidak menimbulkan adanya prasangka tertentu terhadap aktoraktor sosial yang terlibat di dalam pemberitaan. Bagi peneliti selanjutnya yang ingin mengkaji pendekatan analisis wacana kritis Theo van Leeuwen disarankan untuk mengidentifikasi terlebih dahulu objek material dan sumber data yang akan digunakan, sehingga pemerolehan data dapat ditemukan secara menyeluruh, baik pada bagian eksklusi maupun inklusi. Selain itu, pemberitaan dengan tema tindak kejahatan dapat dijadikan sebagai alternatif untuk mengungkap ciri ideologi tersembunyi dengan menggunakan model analisis wacana kritis lainnya.

\section{DAFTAR PUSTAKA}

Arsa, L. A., dan Syam, H. M. (2019). Analisis Wacana Pemberitaan Prostitusi Online Pada Harian Serambi Serambi Indonesia. 4(2). www.jim.unsyiah.ac.id/FISIP

Badudu, J. S. (2000). Kamus Umum Bahasa Indonesia. Pustaka Sinar Harapan. 
Program Studi Pendidikan Bahasa dan Sastra Indonesia FKIP Universitas Kuningan

Darma, Y. A. (2014). Analisis Wacana Kritis (Dalam Multiperspektif). PT Refika Aditama.

Fairclough, N (1995). Critical Discourse Analysis: The Critical Study of Language. logman.

Fauzan, U. (2014). Analisis Wacana Kritis dari Model Fairclough hingga Mills. $6(1)$.

https://d1wqtxts1xzle7.cloudfront.ne $\mathrm{t} / 47096548 /$

Hartanto, B. H., Rochmah, E. C., dan Goziyah. (2020). Critical Discourse Analysis of Theo Van Leeuwen's Inclussion Theory on Anti-Crime Editorials in Daily Newspapers Pos Kota February 2020 Edition. 4(1). http://doi.org/10.21009/AKSIS

Hura, D., Manaf, N. A., dan Ramadhan, S. (2020). Pemosisian Pelaku dan Korban dalam Berita Kriminal tentang Pembunuhan Berita Online Tribun News.com. 32(1). https://aksara.kemdikbud.go.id/jurna 1/index.php/aksara/article/view/522

Kholid. (2018). The Abstract of Critical Discourse Analysis of Radicalism Labeling by BNPT to Islamic Site. 4(4).

https://sloap.org/journals/index.php/ ijllc/article/view/277

Leeuwen, T. van. (2008). Discourse and Practice New Tools for Critical Discourse Analysis. Oxford University Press.

Marheni, K. S., Kumbara, A. A. N. A., Wiasti, N. M., \& Liando, M. R. (2020). Ideology Behind Character Value Discourse in a Balinese Pop Song.

$6(1)$. https://doi.org/10.21744/ijllc.v6n1.8 $\underline{21}$

Masitoh. (2020). Pendekatan Dalam Analisis Wacana Kritis. 18(1). https://jurnal.umko.ac.id/index.php/ elsa/article/view/221

Othman, A. A. M. (2019). Fundamentalist and Tolerant Islamic Discourse in John Updike's Terrorist and Jonathan Wright's Translation The Televangelist: A Corpus-based Critical Discourse Analysis of Semantic Prosody. 5(6). https://doi.org/10.21744/ijllc.v5n6.7 47

Pramita, C., Ramadhan, S., Tressyalina, \& Afnita. (2019). Analisis Wacana Kritis Pada Pemberitaan Online Tempo.co Tentang Pilpres 2019. 5(2). $\quad$ http://ejournal.stkip-pgrisumbar.ac.id/index.php/jurnalgramatika/index

Rilma, A. F., Syahrul, R., dan Gani, E. (2019). Strategi Pemberitaan di Media Online Nasional tentang Kasus Tercecernya KTP Elektronik (Analisis Teori van Leeuwen). 15(1). http://journal.unnes.ac.id/nju/index. php/lingua

Sari, W. P. (2018). Analisis Wacana Kritis Kasus Penyerangan Terhadap Jemaah Ahmadiyah di Cikeusik. $10(1)$.

https://journal.untar.ac.id/index.php/ komunikasi/article/view/1507

Sawirman. (2017). Anti-Language, War on Discourse, Agrolinguistic Case, and Museum of Palm Oil in Indonesia. $3(5)$. https://sloap.org/journals/index.ph p/ijllc/article/view/225 